\title{
The Civil War Soldier and the Art of Dying
}

\section{Citation}

Faust, Drew G. 2001. The Civil War soldier and the art of dying. The Journal of Southern History 67(1): 3-38.

\section{Published Version}

http://dx.doi.org/10.2307/3070083

\section{Permanent link}

http://nrs.harvard.edu/urn-3:HUL.InstRepos:2634148

\section{Terms of Use}

This article was downloaded from Harvard University's DASH repository, and is made available under the terms and conditions applicable to Other Posted Material, as set forth at http:// nrs.harvard.edu/urn-3:HUL.InstRepos:dash.current.terms-of-use\#LAA

\section{Share Your Story}

The Harvard community has made this article openly available.

Please share how this access benefits you. Submit a story.

Accessibility 


\title{
The Civil War Soldier and the Art of Dying
}

\author{
By Drew Gilpin Faust
}

Mortality defines the human condition. "We all have our Dead-we all have our Graves," Stephen Elliott, a Confederate Episcopal bishop, observed in an 1862 sermon. Every age, he explained, must confront "like miseries"; every age must search for "like consolation." Yet in spite of the continuities that Elliott identified in human history, death has its discontinuities as well. Men and women fashion the way they approach the end of life out of their understandings of who they are and what matters to them. And inevitably these understandings are shaped by historical and cultural circumstances, by how others around them regard death, by conditions that vary over time and place. Even though "we all have our Dead" and even though we all die, we are likely to do so quite differently from century to century or even generation to generation, from continent to continent and from nation to nation. ${ }^{1}$

In the middle of the nineteenth century the United States embarked on a new relationship with death, entering into a civil war that proved bloodier than any other conflict in American history, a war that would presage the slaughter of World War I's Western Front and the global carnage of the twentieth century. The number of soldiers who died between 1861 and 1865 is approximately equal to American fatalities

\footnotetext{
' [Stephen Elliott], Obsequies of the Rev. Edward E. Ford, D.D., and Sermon by the Bishop of the Diocese ... (Augusta, Ga., 1863), 8. For a thoughtful consideration of the art of dying in contemporary culture see Anne Hunsaker Hawkins, "Constructing Death: Myths about Dying," in Reconstructing Illness: Studies in Pathography (West Lafayette, Ind., 1993), 91-124. I would like to thank Charles Rosenberg, Barbara Savage, Steven Stowe, David Nord, Reid Mitchell, and Tony Horwitz for comments on this essay. I am also grateful for the helpful responses of groups to whom earlier versions of this paper were presented: Peter Stallybrass's Seminar on the History of Material Texts, the Philadelphia Old Baldy Civil War Roundtable, and audiences at Penn State, the University of Texas, and the Missouri Historical Society.
}

Ms. FAUST is Dean of the Radcliffe Institute for Advanced Study and Professor of History at Harvard University. She delivered this paper on November 9,2000 , as the presidential address at the sixty-sixth annual meeting of the Southern Historical Association in Louisville, Kentucky. 
in the Revolution, the War of 1812, the Mexican War, the Spanish American War, World War I, World War II, and the Korean War combined. The Civil War's rate of death, its incidence in comparison with the size of the American population, was six times that of World War II; a similar rate of death, about 2 percent, in the United States today would mean almost five million fatalities. Although mortality rates differed North and South, with the percentage of Confederate men who died in the war three times greater than the proportion of Yankees, death seemed omnipresent throughout Civil War America. As the Daily South Carolinian observed in 1864, "Carnage floods our once happy land."

But the impact and meaning of the war's casualties were not simply a consequence of scale, of the sheer numbers of Union and Confederate soldiers who died. Death's significance for the Civil War generation derived as well from the way it violated prevailing assumptions about life's proper end-about who should die, when and where, and under what circumstances. As a newly appointed chaplain explained to his Connecticut regiment in the middle of the war, "neither he nor they had ever lived and faced death in such a time, with its peculiar conditions and necessities...." Civil War soldiers and civilians alike distinguished what many referred to as "ordinary death," as it had occurred in prewar years, from the way in which so many men were now dying in Civil War battlefields and camps. ${ }^{3}$ Historians have only recently begun to consider the social and cultural meanings of Civil War death, perhaps because the war was so long seen as the all-but-exclusive province of military historians, who regarded casualties chiefly as an index to an army's continuing strength and effectiveness. Burgeoning recent interest in the war by social historians, however, has begun to

\footnotetext{
${ }^{2}$ Daily South Carolinian, February 26, 1864; see also June 22, 1864. James David Hacker, "The Human Cost of War: White Population in the United States, 1850-1880" (Ph.D. diss., University of Minnesota, 1999), 1, 14. Hacker believes that Civil War death totals may be significantly understated because of inadequate estimates of the number of Confederate deaths from disease. Almost twice as many Civil War soldiers died from disease as from battlefield wounds. See also Maris A. Vinovskis, "Have Social Historians Lost the Civil War?" in Vinovskis, ed., Toward a Social History of the American Civil War: Exploratory Essays (Cambridge, Eng., and other cities, 1990), 3-7; Drew Gilpin Faust, "A Riddle of Death": Mortality and Meaning in the American Civil War (Gettysburg, Pa., 1995); and Faust, "Christian Soldiers: The Meaning of Revivalism in the Confederate Army," Journal of Southern History, LIII (February 1987), 63-90. On the melodramatic rendering of the meaning of the war and death's centrality to this understanding, see Alice Fahs, The Imagined Civil War: Popular Literature of the North and South, 1861-1865 (Chapel Hill and London, 2001), 93-119, 300.

${ }^{3}$ H[enry] Clay Trumbull, War Memories of an Army Chaplain (New York, 1898), 67; Earl J. Hess, The Union Soldier in Battle: Enduring the Ordeal of Combat (Lawrence, Kans., 1997), 38.
} 
raise questions about the wider impact of battlefield slaughter and to suggest that such mortality, even in a society far more accustomed to death than our own, must have exerted a profound influence on Americans' perceptions of the world around them as well as their hopes for a world to come. Like the Connecticut chaplain, these scholars see Civil War death as representing a new departure-in its scale, in its brutality, in its seeming endlessness as the war continued on and on. The Mexican War had yielded a total of 1,800 American military deaths over a period of two years; the Revolution killed approximately 4,000 . More than 4,800 soldiers died on a single day at Antietam in September 1862, and 7,000 more would die from wounds received there. Death was no longer just encountered individually; mortality rates were so high that nearly every American family was touched. Death's threat, its proximity, its actuality became the most widely shared of war's experiences. As Emily Dickinson wrote from western Massachusetts during the conflict, "Sorrow seems to me more general [than] it did, and not the estate of a few persons, since the war began; and if the anguish of others helped one with one's own, now would be many medicines." At war's end, this shared suffering would override persisting differences about the meanings of race, citizenship, and nationhood to establish sacrifice and its memorialization as the common ground on which North and South would ultimately reunite. Even in our own time, this fundamentally elegiac understanding of the Civil War retains its powerful hold. ${ }^{4}$

Our understanding of the impact and influence of Civil War mortality must necessarily begin with an exploration of the deaths themselves, with how they were managed emotionally, spiritually, and ideologically by soldiers and their families. Americans North and

\footnotetext{
${ }^{4}$ Emily Dickinson quoted in Shira Wolosky, Emily Dickinson: A Voice of War (New Haven and London, 1984), 36. In his influential 1980 study, Inventing the American Way of Death, James J. Farrell almost managed not to mention the war at all in its overview of the changing place of death in nineteenth-century society; see Farrell, Inventing the American Way of Death, 1830-1920 (Philadelphia, 1980). See also Karen Halttunen, Confidence Men and Painted Women: A Study of Middle Class Culture in America, 1830-1870 (New Haven and London, 1982), whose chapter on "Mourning the Dead" (Chap. 5) does not refer to the Civil War; Faust, "A Riddle of Death"; Gerald F. Linderman, Embattled Courage: The Experience of Combat in the American Civil War (New York, 1987); Phillip Shaw Paludan, "A People's Contest": The Union and Civil War, 1861-1865 (New York, 1988); Gary Laderman, The Sacred Remains: American Attitudes Toward Death, 1799-1883 (New Haven and London, 1996), 124; Hess, The Union Soldier in Battle; and Reid Mitchell, The Vacant Chair: The Northern Soldier Leaves Home (New York, 1993), 135-50. Probably the most influential contemporary example of such an elegiac rendering of the Civil War is Ken Burns's popular television series (The Civil War, Ken Burns, prod. [PBS Video, 1990]).
} 
South would be compelled to confront—and resist—-the war's assault on their conceptions of how life should end, an assault that challenged their most fundamental assumptions about life's value and meaning. As they faced horrors that forced them to question their ability to cope, their commitment to the war, even their faith in a righteous God, soldiers and civilians alike struggled to retain their most cherished beliefs, to make them work in the dramatically altered world that war had introduced. Civil War death would transform America and Americans in ways that new scholarship is just beginning to explore. But this change would emerge only slowly and only out of the often desperate efforts of Yankees and Confederates to mobilize traditional religious and intellectual resources to operate in the dramatically changed circumstances of what has often been called the first modern and the last old-fashioned war. In the experiences of soldiers and their families, we can see this conflict between old and new cast into sharp relief as Americans endeavored to reconstruct conventional consolations to serve new times and a new kind of slaughter. Civil War death must thus be understood as at once old and new, for the effort of Americans to hold on to cherished beliefs and assumptions indelibly shaped the necessarily transformed world that war made.

Mid-nineteenth-century American culture treated dying as an art and the "Good Death" as a goal that all men and women should struggle to achieve. From the fifteenth century onward, texts describing the Ars Moriendi ["art of dying"] had provided readers with rules of conduct for the moribund and their attendants: how to give up one's soul "gladlye and wilfully"; how to meet the devil's temptations of unbelief, despair, impatience, and worldly attachment; how to pattern one's dying on that of Christ; how to pray. With the spread of vernacular printing, such texts multiplied in number, culminating in the midseventeenth century with Jeremy Taylor's The Rule and Exercise of Holy Dying (1651). Taylor, an Anglican divine, has been called a "prose Shakespeare." His revision of the originally Catholic Ars Moriendi was not just an example of literary art, however, but an intellectual triumph that succeeded in firmly establishing the genre within Protestantism. Taylor, who had already published a volume on holy living, placed deathbed conduct within the context of the whole life that served as its preparation. ${ }^{5}$

\footnotetext{
5 Jeremy Taylor, The Rule and Exercises of Holy Dying (London, 1651); Jeremy Taylor, The Rule and Exercises of Holy Living (London, 1650); Mary Catherine O'Connor, The Art of Dying Well: The Development of the Ars Moriendi (New York, 1942), 7 (first quotation), 208 (second
} 


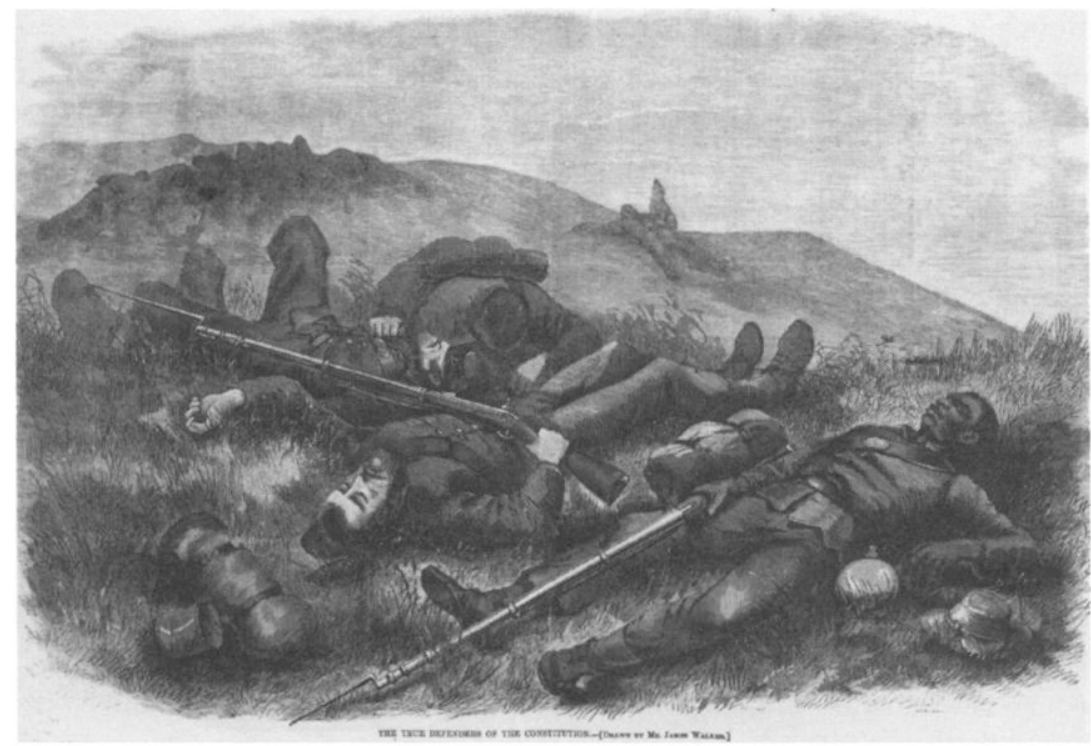

"The True Defenders of the Constitution." Illustration by James Walker, from Harper's Weekly, November 11, 1865, p. 712.

Reproduced by permission of the Library Company of Philadelphia.

By the nineteenth century Taylor's books had become classics, and the tradition of the Ars Moriendi spread both through reprints of earlier texts and through more contemporary considerations of the Good Death. Often these more modern renditions appeared in new contexts and genres: in sermons that focused on one or two aspects of the larger subject; in American Sunday School Union tracts distributed to youth across the nation; in popular health books that combined the expanding insights of medical science with older religious conventions about dying well; or in popular literature, with the exemplary deaths of Dickens's Little Nell, Thackeray's Colonel Newcome, or Harriet

quotation, from Samuel Coleridge). See also L. M. Beier, "The Good Death in SeventeenthCentury England," in Ralph Houlbrooke, ed., Death, Ritual, and Bereavement (New York, 1989); Ralph Houlbrooke, Death, Religion, and the Family in England, 1480-1750 (Oxford, 1998); Houlbrooke, "The Puritan Death-bed, c. 1560-c. 1600," in Christopher Durston and Jacqueline Eales, eds., The Culture of English Puritanism, 1560-1700 (New York, 1996) 122-44; M. Claire Cross, "The Third Earl of Huntingdon's Death-Bed: A Calvinist Example of the Ars Moriendi," Northern History, XXI (1985), 80-107; Richard Wunderli and Gerald Boce, "The Final Moment Before Death in Early Modern England," Sixteenth Century Journal, XX (Summer 1989), 25975; David Cressy, Birth, Marriage, and Death: Ritual, Religion, and the Life-Cycle in Tudor and Stuart England (New York and Oxford, 1997). 
Beecher Stowe's Eva. So diverse and numerous were these representations of the Good Death that they reached a wide spectrum of the American population at mid-century, and they would become a central aspect of the popular culture, the songs, stories, and poetry of the Civil War itself. By the 1860s many elements of the Good Death had been to a considerable degree separated from their explicitly theological roots and had become as much a part of respectable middle-class behavior and expectation in both North and South as they were the product or emblem of any particular religious affiliation. Assumptions about the way to die remained central within both Catholic and Protestant faiths but had spread beyond formal religion to become a part of more general systems of belief held across the nation about life's meaning and life's appropriate end. ${ }^{6}$

In the context of the Civil War, the Good Death proved to be a concern shared by almost all Americans of every religious background. An overwhelming majority of Civil War soldiers, like Americans generally in the 1860 s, were Protestant, and Protestant assumptions dominated discourse about death. But war's imperatives for unity and solidarity produced an unprecedented degree of religious interaction and cooperation that not only brought Protestant denominations together but to a considerable extent incorporated Catholics and Jews as well. The war encouraged a Protestant ecumenism that yielded interdenominational publication societies, common evangelical gatherings, and shared charitable efforts like the Christian Commission. But Civil

\footnotetext{
${ }^{6}$ Frances M. M. Comper, ed., The Book of the Craft of Dying and Other Early English Tracts Concerning Death (London and other cities, 1917); Nancy Lee Beaty, The Craft of Dying: A Study in the Literary Tradition of the Ars Moriendi in England (New Haven and London, 1970); Taylor, Rule and Exercises of Holy Dying. At least eight editions of Holy Dying appeared in London in the first half of the nineteenth century; editions were printed in Boston in 1864 and 1865; in Philadelphia in 1835, 1859, and 1869; and New York in 1864. On conceptions of Ars Moriendi included in advice and conduct books, see Margaret Spufford, Small Books and Pleasant Histories: Popular Fiction and Its Readership in Seventeenth-Century England (Athens, Ga., 1981), 200-208. For an example of a sermon see Eleazer Mather Porter Wells, Preparation for Death . . Trinity Church, Boston (1852, n.p.). On popular health see the many American editions of John Willison, The Afflicted Man's Companion (Pittsburgh, 1830), which was reprinted again by the American Tract Society of New York in 1851. So popular was Dickens's serialized The Old Curiosity Shop that New Yorkers lined the quay for the arrival of the installment that would reveal Little Nell's fate. Harriet Beecher Stowe's Uncle Tom's Cabin was among the best-selling American books of the nineteenth century. Charles Dickens, The Old Curiosity Shop (London, 1841); William Makepeace Thackeray, The Newcomes: Memoirs of a Most Respectable Family (London, 1854-55); Harriet Beecher Stowe, Uncle Tom's Cabin, or Life Among the Lowly (Boston, 1852). On Stowe see Mary Kelley, Private Woman, Public Stage: Literary Domesticity in Nineteenth-Century America (New York and Oxford, 1984), 14, 26; on Dickens, see James D. Hart, The Popular Book: A History of America's Literary Taste (New York, 1950), 102. Cf. the rendition of death in Samuel Richardson's Clarissa, or, the History of a Young Lady (London, 1748).
} 
War ecumenism extended beyond Protestantism. Catholic chaplains in both Union and Confederate armies remarked on the effective cooperation among pastors and soldiers of differing religious affiliations. One of the most famous religious images of the war, Father William Corby offering a ceremony of general absolution to a brigade of Union troops before their engagement at Gettysburg, serves as a telling representation of the way that war's necessities produced a widely shared culture of religious faith, at least temporarily distanced from theological particulars. As Corby described the event, "all, Catholic and nonCatholic ... soldiers showed a profound respect, wishing at this fatal crisis to receive every benefit of divine grace that could be imparted ...." The chaplain added that "general absolution was intended for all ... not only for our brigade, but for all, North or South, who were susceptible of it and who were about to appear before their Judge." 7

Even Jewish soldiers, who comprised less than 0.3 percent of Civil War armies, partook of this common religiosity. Michael Allen, Jewish chaplain of a Pennsylvania regiment, held nondenominational Sunday services for his men, preaching on a variety of topics, including proper preparation for death. Although we today tend to assume sharp differences between Jewish and Christian views of death, and particularly the afterlife, these contrasts appeared far less dramatic to midnineteenth-century Americans. Drawing on traditions stretching back at least to Maimonides, Jews of the Civil War era shared with their Christian counterparts anticipations, as one condolence letter put it, of "a better life" to come. Rebecca Gratz of Philadelphia could console her sister-in-law that her son, killed at the Battle of Wilson's Creek, and his distraught father "shall be united in another world." 8 Civil War

\footnotetext{
${ }^{7}$ William Corby, Memoirs of Chaplain Life (Notre Dame, Ind., 1894), 184. Memorials to this moment are located at Notre Dame and on the field at Gettysburg. It has been estimated that Catholics comprised about 7 percent of Union armies. They would have been a far smaller percentage of Confederate soldiers. See Randall M Miller, "Catholic Religion, Irish Ethnicity, and the Civil War," in Randall M. Miller, Harry S. Stout, and Charles Reagan Wilson, eds., Religion and the American Civil War (New York and Oxford, 1998), 261.

${ }^{8}$ Bertram W. Korn, American Jewry and the Civil War (Philadelphia, 1951), 59; D[avid]. de Sola Pool, "The Diary of Chaplain Michael M. Allen, September 1861," Publications of the American Jewish Historical Society, XXXIX (September 1949), 177-82; L. J. Lederman, letter to parents of David Zehden upon his death, quoted in Mel Young, Where They Lie: The Story of the Jewish Soldiers ... (Lanham, Md., New York, and London, 1991), 149; Rebecca Gratz, Letters of Rebecca Gratz, edited by David Philipson (Philadelphia, 1929), 424-27 (quotation on p. 427). See also From This World to the Next: Jewish Approaches to Illness, Death and the Afterlife (New York, 1999); and Jack Riemer, ed., Wrestling with the Angel: Jewish Insights on Death and Mourning (New York, 1995), 309-53. On ecumenism see Korn, American Jewry, 59; Warren B. Armstrong, For Courageous Fighting and Confident Dying: Union Chaplains in the
} 
death thus proved a great equalizer in its effect of minimizing - or perhaps more accurately, marginalizing-theological and denominational differences. The shared crisis of battle yielded a common effort to cope with death's ascendancy in order to salvage the comforting notion of a Good Death available to all those who were caught up in the maelstrom of war. ${ }^{9}$

At the heart of this common understanding lay the assumption of death's transcendent importance. A tract distributed to Confederate soldiers by the Presbyterian Church warned that "Death is not to be regarded as a mere event in our history. It is not like a birth, or a marriage, or a painful accident, or a lingering sickness." It has an "importance that cannot be estimated by men." Death's significance arose from its absolute and unique permanence. "Death fixes our state. Here [on earth] everything is changing and unsettled. Beyond the grave our condition is unchangeable." The moment of death could thus offer a glimpse of an unvarying perpetuity. "What you are when you die, the same will you reappear in the great day of eternity. The features of character with which you leave the world will be seen in you when you rise from the dead." How one died thus epitomized a life already led and predicted the quality of the life everlasting. The hors mori, the hour of death, had, therefore, to be witnessed, scrutinized, interpreted, narrated - not to mention carefully prepared for by any sinner seeking to

Civil War (Lawrence, Kans., 1998), 53-54; Kurt O. Berends, “'Wholesome Reading Purifies and Elevates the Man': The Religious Military Press in the Confederacy," in Miller, Stout, and Wilson, eds., Religion and the American Civil War, 134, 157 n. 8; Thomas McAvoy, ed., "The War Letters of Father Peter Paul Cooney of the Congregation of the Holy Cross," in Records of the American Catholic Historical Society, LXIV (1933), 223, 164; Cornelius M. Buckley, trans., A Frenchman, A Chaplain, A Rebel: The War Letters of Pere Louis-Hippolyte Gache, S.J. (Chicago, 1991), 176-77, 118-19; Sara Trainer Smith, ed., "Notes on Satterlee Hospital, West Philadelphia," Records of the American Catholic Historical Society, VIII (1897), 404. On limitations to that ecumenism see Buckley, trans., A Frenchman, A Chaplain, A Rebel, 190-91.

${ }^{9}$ African American soldiers seemed to have shared these assumptions as well. As one black Civil War correspondent noted in 1864, they were "nearly all professors of religion" and overwhelmingly Protestant in their affiliations. R. J. M. Blackett, ed., Thomas Morris Chester, Black Civil War Correspondent: His Dispatches from the Virginia Front (Baton Rouge and London, 1989), 117. Although I have not found a surviving body of condolence letters concerning the deaths of black soldiers, essays in the African American press during the Civil War suggest shared views about the Good Death and its significance. See, for example, correspondent George Stephens's remarks in the New York Weekly Anglo-African, April 26, 1862; see also "Incidents of Love, Hate, and Piety on the Battle-field," August 31, 1861, and "An Affecting Scene," June 8, 1861, both in the Philadelphia Christian Recorder; and "The Funeral of Captain Andre Cailloux," in Harper's Weekly, August 29, 1863. African American commentary on death, however, also seemed frequently to involve the theme of retribution. See Faust, "Riddle of Death," 25; on the importance of this theme in the rhetoric of Frederick Douglass see David W. Blight, Frederick Douglass' Civil War: Keeping Faith in Jubilee (Baton Rouge and London, 1989), 109. I plan to more fully develop this theme elsewhere. 
demonstrate worthiness for salvation. The sudden and all-butunnoticed end of the soldier slain charging amidst the chaos of battle, the unattended deaths of unidentified wounded men too ill to reveal their last thoughts, denied these long-cherished consolations. Civil War battlefields could have provided the material for an exemplary text on how not to die. ${ }^{10}$

Soldiers and their families struggled in a variety of ways to mitigate such cruel realities, to construct a Good Death even amidst chaos, to substitute for missing elements or compensate for unsatisfied expectations. Their successes or failures influenced not only the last moments of thousands of dying soldiers but also the attitudes and outlook of survivors who contended with the impact of these experiences for the rest of their lives.

By the beginning of the 1860s the rate of death in the United States had begun to decline, although dramatic improvements in longevity would not appear until late in the century. Americans of the immediate pre-Civil War era continued to encounter death with greater frequency and familiarity than their twentieth-century counterparts. But the patterns to which they were accustomed were in significant ways different from those war would bring. Mid-nineteenth-century Americans experienced a high rate of infant mortality but expected most individuals who had reached young adulthood to survive at least into middle age. One of the most "peculiar" of the "conditions" surrounding Civil War death, one of the most significant ways in which it departed from "ordinary" death, was that it took young, healthy men and rapidly, often instantly, destroyed them with disease or injury. This represented a sharp and alarming departure from prevailing assumptions about who should die. As Francis W. Palfrey of Massachusetts wrote in an 1864 memorial for Union soldier Henry L. Abbott, "the blow seems heaviest when it strikes down those who are in the morning of life." 11

${ }^{10}$ Once to Die, Presbyterian Committee of Publication, No. 45 (Richmond, Va., n.d. [18611865]; microfilm, Confederate Imprints [New Haven, 1974], reel 135), 3. See also Karl S. Guthke, Last Words: Variations on a Theme in Cultural History (Princeton, 1992), 36.

${ }^{11}$ [Francis W. Palfrey], In Memoriam: H[enry]. L. A[bbott]. (Boston, 1864; microfiche, Selected Americana from Sabin's Dictionary . . . [Woodbridge, Conn., 1998]), 5. Vital statistics for this period are very scarce, and the most complete cover only Massachusetts. My thanks to historical demographer Gretchen Condran of Temple University for discussing these matters with me. See U.S. Bureau of the Census, Historical Statistics of the United States, Part I (Washington, 1975), 62-63. On the "untimely death of an adult child" as "particularly painful" in midnineteenth-century England, see Patricia Jalland, Death in the Victorian Family (Oxford and New York, 1996), 39. On the expectation that one would die at home, see Robert V. Wells, Facing the "King of Terrors": Death and Society in an American Community, 1750-1990 (Cambridge, Eng., and other cities, 2000), 195. 
But perhaps the most distressing aspect of death for many Civil War-era Americans was that thousands of young men were dying away from home. As one group of Confederate prisoners of war observed in a resolution commemorating a comrade's death in 1865 , "we . . deplore that he should die . . in an enemys land far from home and friends." Most soldiers would have shared the wishes of the Georgia man whose brother sadly wrote after his death in Virginia in 1864, "he always did desire . . to die at home." As a South Carolina woman observed in 1863 , it was "much more painful" to give up a "loved one [who] is a stranger in a strange land." 12

Civil War soldiers experienced an isolation from relatives uncommon among the free white population. Civil War armies, moreover, segregated men from women, who in the nineteenth century bore such a significant part of the responsibility for care of both the living and the dead. As a Sanitary Commission observer remarked of the Army of the Potomac, "Of this hundred thousand men, I suppose not ten thousand were ever entirely without a mother's, a sister's, or a wife's domestic care before." 13

Family was central to the Ars Moriendi tradition, for kin performed its essential rituals. Victorian ideals of domesticity further reinforced these assumptions about death's appropriate familial setting. As a British social historian has explained in an observation that would apply equally well to nineteenth-century America, "the family was the primary Victorian and Edwardian social institution in which the meaning of individual deaths was constructed and transmitted across the generations." 14 One should die amidst family assembled around the deathbed. Relatives would of course be most likely to show concern about the comfort and needs of their dying loved one, but this was

\footnotetext{
${ }^{12}$ Minutes, March 31, 1865, Confederate States Christian Association for the Relief of Prisoners (Fort Delaware), Francis Atherton Boyle Books, Southern Historical Collection (University of North Carolina at Chapel Hill) (first quotation); James Gray to Sister, June 12, 1864, in Mills Lane, ed., Dear Mother: Don't Grieve About Me. If I Get Killed, I'll Only Be Dead: Letters from Georgia Soldiers in the Civil War (Savannah, Ga., 1990), 300 (second quotation); and unsigned letter to Mattie J. McGaw, May 5, 1863, McGaw Family Papers, South Caroliniana Library, University of South Carolina, Columbia (third quotation). See also William Stilwell to wife [Molly], September 18, 1862, in Lane, ed., Dear Mother, 185.

${ }^{13}$ Frederick Law Olmsted, comp., Hospital Transports: A Memoir of the Embarkation of the Sick and Wounded from the Peninsula of Virginia in the Summer of 1862 (Boston, 1863), 80. Disruptions of African American family ties through the slave trade to the southwestern states was, of course, another matter-both in its coerciveness and its permanence; see Michael Tadman, Speculators and Slaves: Masters, Traders, and Slaves in the Old South (Madison, Wis., 1989).

${ }^{14}$ Jalland, Death in the Victorian Family, 2. The English queen's own lengthy bereavement after Albert's death in 1861 focused additional attention on death as a defining element in Anglo-American family and cultural life.
} 
ultimately a secondary consideration. Far more important, family members needed to witness a death in order to assess the state of the dying person's soul, for these critical last moments of life would epitomize his or her spiritual condition. Kin would use their observations of the deathbed to evaluate the family's chances for a reunion in heaven. A life was a narrative that could only be incomplete without this final chapter, without the life-defining last words.

Last words had always held a place of prominence in the Ars Moriendi tradition. By the eighteenth century, "dying declarations" had assumed - and still retain-explicit secular importance: a special evidentiary status excepting them from legal rules excluding hearsay. Final words were regarded as possessing an especially high truth status, both because it was believed that a dying person could no longer have any earthly motivation to lie and because those about to meet their Maker would not wish to expire bearing false witness. As Civil War sermonizers North and South reminded their congregations, "A deathbed's a detector of the heart." Not only were last words important because of their assumed honesty, they also imposed a meaning on the life narrative they would conclude. At the same time that they exemplified a life, moreover, they communicated invaluable lessons or insights to those gathered around the deathbed. This educational function provided a critical means through which the deceased could continue to exist in the lives of the survivors. The teachings that last words imparted served as a lingering exhortation and a persisting tie between the living and the dead. To be deprived of these lessons and thus this connection seemed unbearable to many nineteenth-century Americans left at home while their sons, husbands, and brothers died with their last words unrecorded or even unheard. ${ }^{15}$

\footnotetext{
${ }^{15}$ The Dying Officer (Richmond, Va., n.d. [1860s]; microfilm, Confederate Imprints, reel 134), 6; Hiram Mattison quoted in Michael Sappol, "A Traffic in Dead Bodies": Anatomical Dissection and Embodied Social Identity in Nineteenth-Century America (Princeton, forthcoming), Chap. 2, p. 28 (citation is to manuscript page). I am grateful to Professor Sappol for letting me see his unpublished manuscript. On dying declarations see Guthke, Last Words, 27-28; on the evidentiary status of last words see John Henry Wigmore, Evidence in Trials at Common Law (Boston, 1904; rev. ed., 1974), Vol. V, 289 ("The utterances of the dying person are to be taken as free from all ordinary motives to misstate."). See also John William Strong, ed., McCormick on Evidence (4th ed., St. Paul, Minn., 1992), 523-27. My thanks to Albert J. Beveridge III, Sarah Gordon, and Kim Schepple for their advice on legal history. There is evidence of dying declarations granted hearsay exception from at least the early eighteenth century, always in cases of murder victims naming their killers; see Wigmore, Evidence at Trials, Vol. V, Chap. 49. See also the statement on the meaning of last words in Susie C. Appell to Mrs. E. H. Ogden, October 20, 1862, Ogden Papers, Gilder-Lehrman Collection, Morgan Library, New York City, as well as the discussion of the significance of last words in Frank Leslie's Illustrated Weekly, December 7, 1861, p. 44
} 
The effort to overcome separation from kin and to provide a surrogate for the traditional stylized deathbed performance lay at the heart of Civil War-era efforts to manage battlefield death. Soldiers, chaplains, military nurses, and doctors conspired to provide the dying man and his family with as many of the elements of the conventional Good Death as possible, struggling even amidst the chaos of war to make it possible for men - and their loved ones - to believe they had died well. Spiritual wounds demanded attention as powerfully as did those of the flesh. ${ }^{16}$

Determined not to die alone, soldiers worked to provide themselves with replacements, proxies for those who might have surrounded their deathbeds at home. Battlefield descriptions often remark on the photographs found alongside soldiers' corpses. In March 1864, for example, Godey's Ladies' Book reported the death of a soldier discovered with pictures of his three children "tightly clasped in his hands." Denied the presence of actual kin, dying men removed pictures from pockets or knapsacks and spent their last moments communicating with these representations of absent loved ones. In military hospitals, nurses frequently cooperated in this search for substitutes, permitting delirious soldiers to think their mothers, wives, or sisters stood nearby. In a famous lecture with which she toured the country in the years after the war, Clara Barton described her crisis of conscience when a young man on the verge of death mistook her for his sister Mary. Unable to bring herself actually to address him as "brother," she nevertheless kissed his forehead so that, as she explained, "the act had done the falsehood the lips refused to speak." 17

Perhaps Clara Barton was familiar with some of the popular Civil War-era songs that portrayed her situation almost exactly: the plea of the expiring soldier requesting his nurse to "Be My Mother Till I Die," or even the lines of the nurse herself:

Let me kiss him for his mother, Or, perchance, a sister dear;

Farewell, dear stranger brother, Our requiem, our tears.

\footnotetext{
${ }^{16}$ See Gregory A. Coco, Killed in Action: Eyewitness Accounts of the Last Moments of 100 Union Soldiers Who Died at Gettysburg (Gettysburg, Pa., 1992); Coco, Wasted Valor: The Confederate Dead at Gettysburg (Gettysburg, Pa., 1990); Armstrong, For Courageous Fighting.

17 "Reminiscence of Gettysburg," Frank Leslie's Illustrated Newspaper, January 2, 1864, p. 235; on photographs see Steven R. Stotelmyer, The Bivouacs of the Dead: The Story of Those Who Died at Antietam and South Mountain (Baltimore, 1992), 6; Godey's Ladies Book, March 1864, p. 311; Clara Barton, Lecture Notes [1866], Clara Barton Papers, Library of Congress.
} 
This song was so widely sung it prompted a reply, which was published as an "ANSWER TO: Let me kiss him for his mother." Written in the voice of those who remained at home, the ballad expressed gratitude to the women caring for the wounded at the same time it sought to reassure wives and mothers that their loved ones were not dying alone.

Bless the lips that kissed our darling, As he lay on his death-bed,

Far from home and 'mid cold strangersBlessings rest upon your head.

O my darling! O our dead one! Though you died far, far away,

You had two kind lips to kiss you, As upon your bier you lay....

You had one to smooth your pillow, You had one to close your eyes. ${ }^{18}$

The original song and its "Answer" represented an interchange between soldiers and civilians, between men and women, as they struggled together to reconstruct the Good Death amid the disruptions of war, to maintain the traditional connections between the dying and their kin that defined the Ars Moriendi. The inability to witness the last moments of a brother, husband, or child shattered expectations about an appropriate earthly conclusion to these important human connections. A father who arrived to find his son just hours after he died of wounds received at Fredericksburg wrote feelingly of his disappointment-and described his vision of how his son should have died. "If I could have got to our child, and spoken loving and encouraging words to him, and held his dear hand in mine, and received his last breath: but it was not so to be." Yet, denied his deathbed role, the parent had at least achieved one of his purposes: he had acquired definite knowledge of his son's fate. ${ }^{19}$

No effective system of reporting casualties operated on either side during the war. Families most often learned of the deaths of loved ones

${ }^{18}$ Elmer Ruan Coates, Be My Mother Till I Die, broadside, (Philadelphia, 1863); Let Me Kiss Him for His Mother, broadside, (Philadelphia, n.d. [1861]) (Originally written in 1859 about the death from yellow fever in New Orleans of a young man from Maine, this song gained popularity under wartime conditions shortly after its publication); J. A. C. O'Connor, Bless the Lips that Kissed Our Darling. Answer to: Let Me Kiss Him for His Mother, broadside, (New York, n.d. [1860s]). See also George Cooper, Mother Kissed Me In My Dream, broadside (Philadelphia, n.d. [1864]). All of the broadsides cited in this article are housed at the Library Company of Philadelphia.

${ }^{19}$ William J. Bacon, Memorial of William Kirkland Bacon, Late Adjutant of the Twenty-Sixth Regiment of New York State Volunteers (Utica, N.Y., 1863), 50. 
by scrutinizing unreliable newspaper lists of killed and wounded, lists that were often inaccurate as well as painfully incomplete in their mere enumeration of names with no attempt to explain attendant circumstances. To compensate for the inadequacy of such arrangements, it became customary for a slain soldier's closest companions at the time of his death to write a letter to his next of kin, not just offering sympathy and discussing the disposition of clothes and back pay but providing the kind of information a relative would have looked for in a conventional peacetime deathbed scene. These were condolence letters intended to offer the comfort implicit in the narratives of the Ars Moriendi that most of them contained. News of a Good Death represented the ultimate solace - the consoling promise of life everlasting. ${ }^{20}$

Some soldiers tried to establish formal arrangements to ensure the transmission of such information, to make certain that not just the fact but a description of their death would be communicated to their families. In 1862 Williamson D. Ward of the Thirty-Ninth Indiana made a pact with several members of his company to provide this assurance for one another. In the Union prison at Fort Delaware, captured Confederate officers formed a Christian Association with a similar purpose. The group's minute book recorded their resolution, passed on January 6, 1865, "making it the duty" of the organization "to ascertain the name of every Confederate off[icer] dying in this prison and the attendant circumstances, and to transmit the same to their nearest friends or relatives." 21

But even without the formality of such resolutions, soldiers performed this obligation. After Gettysburg, W. J. O'Daniel informed Sarah Torrence of her husband Leonidas's death, explaining that the two of them "went into battle side by side," promising each other "if one go[t] hurt to do all we could for him." This letter represented the

\footnotetext{
${ }^{20}$ On condolence letters see Michael Barton, "Painful Duties: Art, Character, and Culture in Confederate Letters of Condolence," Southern Quarterly, XVII (Winter 1979), 123-34; and Barton, Goodmen: The Character of Civil War Soldiers (University Park, Pa., and London, 1981), 57-62. See also William Merrill Decker, Epistolary Practices: Letter Writing in America before Telecommunications (Chapel Hill and London, 1998); and Janet Gurlin Altman, Epistolarity: Approaches to a Form (Columbus, Ohio, 1982). Contemporary guidebooks for letter writers include The American Letter-Writer and Mirror of Polite Behaviour . . (Philadelphia, 1851); and A New Letter-Writer, for the Use of Gentlemen (Philadelphia, 1860). For an acknowledgement of the ritual of the condolence letter in Civil War popular culture, see the song by E. Bowers, Write a Letter to My Mother!, broadside (Philadelphia, n.d. [1860s]).

${ }^{21}$ Williamson D. Ward diary quoted in Joseph Allan Frank and George A. Reaves, eds., "Seeing the Elephant": Raw Recruits at Shiloh (Westport, Conn., and London, 1989), 98; Minutes, July 1864-June 1865, Confederate States Christian Association for the Relief of Prisoners (Fort Delaware), Francis Atherton Boyle Books.
} 
final fulfillment of that obligation. William Fields wrote to Amanda Fitzpatrick about how her husband passed his last hours in a Richmond hospital at the very end of the war: "As you in all probability have not heard of the death of your husband and as I was a witness to his death I consider it my duty to write to you although I am a stranger to you." Duty similarly motivated I. G. Patten of Alabama to respond with "Aufaul knuse" to a letter that arrived in camp from I. B. Cadenhead's wife almost two weeks after his battlefield death. Another Confederate castigated himself for not stopping in the aftermath of an 1863 battle to record an enemy soldier's last words and transmit them to his family. In retrospect, this seemed to the young rebel a far more egregious failure than not providing water to the thirsty man. ${ }^{22}$

Remarkably similar North and South, condolence letters constitute a genre that emerged from the combination of the assumptions of Ars Moriendi with the "peculiar conditions and necessities" of the Civil War. These letters sought to make absent loved ones virtual witnesses to the dying moments they had been denied, to mend the fissures war had introduced into the fabric of the Good Death. In camp hospitals, nurses and doctors often took on this responsibility, sending the bereaved detailed descriptions not just of illnesses and wounds, but of last moments and last words. Clara Barton kept a notebook filled with such declarations to be forwarded to kin. Some hospital personnel even assumed the role of instructors in the art of dying, eliciting final statements and cueing their patients through the enactment of the Good Death. When Jerry Luther lay wounded after the Battle of Yorktown in 1862 , a physician urged him to send a message to his mother. Another soldier, asked by a doctor for his last words to send home, responded by requesting the doctor to provide them. "I do not know what to say. You ought to know what I want to say. Well, tell them only just such a message as you would like to send if you were dying." The expiring soldier obviously regarded the doctor as an expert in the art of dying as well as in medicine. The soldier comprehended that this was a ritual the physician understood far better than he. The Civil War provided a

\footnotetext{
${ }^{22}$ W. J. O'Daniel to Mrs. [Sarah A.] Torrence, quoted in Haskell Monroe, ed., "The Road to Gettysburg: The Diary and Letters of Leonidas Torrence of the Gaston Guards," North Carolina Historical Review, XXXVI (October 1959), 515; William Fields to Mrs. Fitzpatrick, June 8, 1865, Clopton Hospital Papers, Eleanor S. Brockenbrough Library, Museum of the Confederacy (Richmond, Virginia); I. G. Patten to Mrs. [Leusa F.] Cadenhead, August 5, 1864, in "Some Confederate Letters of I. B. Cadenhead," Alabama Historical Quarterly, XVIII (Winter 1956), 569; Henry E. Handerson, Yankee in Gray: The Civil War Memoirs of Henry E. Handerson with a Selection of his Wartime Letters (Cleveland, Ohio, 1962), 62.
} 
context not just for the performance of the traditions of Ars Moriendi, but for their dissemination. Chaplains North and South in fact saw this instruction as perhaps their most important duty toward the soldiers in their spiritual charge, a duty Catholic father William Corby of a New York regiment described as "the sad consolation of helping them ... to die well.,"23

Sometimes soldiers would attempt to eliminate the need for intermediaries in order to narrate their deaths directly. Many carried letters to be forwarded to loved ones if they were killed, but these did not, of course, provide descriptions of final moments or hours. Some men, however, managed to write home as they lay dying, speaking through their pens instead of from the domestic deathbeds that war had denied them. These letters are particularly wrenching, in part because the last words of more than a century ago appear seemingly unmediated on the page, speaking across the years, serving as a startling representation of immortality for a twenty-first-century reader. Jeremiah Gage of the Eleventh Mississippi wrote his mother after Gettysburg, "This is the last you may ever hear from me. I have time to tell you I died like a man.” James R. Montgomery's 1864 letter to his father in Mississippi is rendered all the more immediate by the bloodstains that cover the page. But if the reality of his wounds seems almost present and even tangible, his assumptions about death emphasize the years that distance him from our own time. "This is my last letter to you," he explains. "I write to you because I know you would be delighted to read a word from your dying son." His choice of the word "delight" here-a term that seems strikingly inappropriate within the context of our modern understanding - underlines the importance accorded the words of the dying. Even as his father faced the terrible news of his son's death, Montgomery expected him to have the capacity to be delighted by the delivery of his son's last thoughts. And even in extremis, Montgomery

\footnotetext{
${ }^{23}$ William Fields to Mrs. Fitzpatrick, June 8, 1865, Clopton Hospital Papers; Clara Barton, Manuscript Journal, 1863, Barton Papers; see also Elizabeth Brown Pryor, Clara Barton: Professional Angel (Philadelphia, 1987), 94, 148; "Our Army Hospitals," clipping, Madeira Scrapbook, Vol. A, Library Company of Philadelphia; Corby, Memoirs, 93. For an example of a nurse cueing a soldier to leave a message for his wife, see William H. Davidson, ed., War Was the Place: A Centennial Collection of Confederate Soldier Letters, Chattahoochie Valley Historical Society Bulletin No. 5 (November 1961), 117. On the important role of hospital personnel in good death, see Laderman, Sacred Remains, 131; and Linderman, Embattled Courage, 29. See also Jestin Hampton to Thomas B. Hampton, January 25, 1863, Thomas B. Hampton Papers; and S. G. Sneed to Susan Piper, September 17, 1864, Benjamin Piper Papers, both in the Center for American History, University of Texas, Austin.
} 
followed the generic form of the Civil War death letter. By the middle of the 1864 Wilderness campaign, Montgomery may well have had a good deal of practice at writing such letters to other families. Now he could use this proficiency in composing his own. ${ }^{24}$

Letters describing soldiers' last moments on earth are so similar, it seems almost as if their authors had a checklist in mind, enumerating the necessary details. In fact, cultural prescriptions about the art of dying specified the elements of a Good Death so explicitly that a letter writer could in large measure anticipate the information that the bereaved would have looked for had they been present at the hour of death: the deceased had been conscious of his fate, had demonstrated his willingness to accept it, had showed signs of belief in God and in his own salvation, and had invoked the idealized domestic deathbed scene by leaving messages and instructive exhortations for those who should have been at his side. But each of these details was in effect a kind of shorthand, conveying to the reader at home a broader set of implications about the dying man's spiritual state and embodying the assumptions that nineteenth-century Americans shared about life and death. ${ }^{25}$

Condolence letters invariably addressed the deceased's awareness of his fate. It was, of course, desirable for the dying man to be conscious and able to confront his impending demise, for only then would he be able to face death's inevitability and thus clearly reveal the state of his soul through his last utterances. One of the Civil War's greatest horrors was that it denied so many soldiers this opportunity by killing them suddenly, obliterating them on the battlefield and depriving them of the

\footnotetext{
${ }^{24}$ Richard Rollins, ed., Pickett's Charge: Eyewitness Accounts (Redondo Beach, Calif., 1994), 96; James R. Montgomery to A. R. Montgomery, May 18, 1864, File M-634E, Brockenbrough Library.

${ }^{25}$ Contrast this "check list" with the "stock messages" Jay Winter describes from British officers in World War I informing relatives of a soldier's death: "[He] was loved by his comrades; he was a good soldier; and he died painlessly." This is a remarkably secular formula in comparison to the Civil War's embrace of the Ars Moriendi tradition. Jay Winter, Sites of Memory, Sites of Mourning: The Great War in European Cultural History (Cambridge, Eng., and New York, 1995), 35. For a Civil War condolence letter written almost in the form of a checklistindentations and all-see John G. Barrett and Robert K. Turner, Jr., eds., Letters of a New Market Cadet: Beverly Stannard (Chapel Hill, 1961), 67-68. For a Catholic example see McEvoy, ed., "War Letters of Father Peter Paul Cooney," 153-54. Much of the "checklist" had its origins in deathbed observers' search for reassurance that a dying person was successfully resisting the Devil's characteristic temptations: to abandon his faith, to submit to desperation or impatience, to demonstrate spiritual pride or complacence, to show too much preoccupation with temporal matters; see Comper, Book of the Craft of Dying, 9-21. For a brief discussion of consolation letters see Mitchell, Vacant Chair, 83-86.
} 
chance for the life-defining deathbed experience. Letter writers were honest in reporting such unsatisfactory deaths, explaining to loved ones at home that they were not alone in being deprived of the last words of the departed.

Sudden death represented a profound threat to the most fundamental assumptions about the correct way to die, and its frequency on the battlefield comprised one of the most important ways that Civil War death departed from the "ordinary death" of the prewar period, as well as one of the most significant challenges the "peculiar conditions" of the Civil War posed to prevailing cultural understandings. When two soldiers calmly eating dinner in a tent were instantly and unexpectedly killed by a shell lobbed from nearby Sullivan's Island, Samuel A. Valentine of the legendary Massachusetts Fifty-Fourth wrote that, although he had seen many comrades die, this incident was especially upsetting, and he declared that he had "never had anything to rest on me so much in my life." The suddenness, the lack of preparation made this death a particularly "awful sight." 26

Readiness was so important in determining the goodness of a death that soldiers often tried to convince themselves and others that even what appeared to be sudden had often in fact been well prepared. Condolence letters sought to provide evidence of the deceased's preparation for his fate. The soldier unable to speak after being struck on the field had in fact, letter writers frequently reassured kin, expressed his faith and demonstrated his anticipations of salvation in the days or weeks before his fatal encounter. When John L. Mason was killed just outside of Richmond in October 1864, a comrade wrote to his mother to explain he "died almost instantly without speaking or uttering a word after being struck." But the letter writer went on to assure her that there still remained "much for consolation" in his death, for even though Mason had been unable to say so, there was evidence that he was "willing and ready to meet his savior." The preceding summer he

\footnotetext{
${ }^{26}$ Edwin S. Redkey, ed., A Grand Army of Black Men: Letters from African American Soldiers in the Union Army, 1861-1865 (Cambridge, Eng., and New York, 1992), 67. Preparation comprised a significant dimension of the Good Death for Jewish soldiers as well; for example, note the emphasis that Albert Moses Luria's family placed on preparedness in his epitaph: "He went into the field prepared to meet his God." Raphael Jacob Moses, Last Order of the Lost Cause: The True Memoirs of a Jewish Family from the "Old South," compiled and edited by Mel Young (Lanham, Md., and London, 1995), 147. On sudden death see also W. D. Rutherford to Sallie F. Rutherford, June 23, 1864, William Drayton Rutherford Papers, South Caroliniana Library; and Houlbrooke, Death, Religion, and the Family, 208.
} 
had told his comrades that he "felt his sins were forgiven $\&$ that he was ready and resigned to the Lord's will \& while talking he was so much overjoyed that he could hardly suppress his feelings of delight." This notion of prepared unpreparedness took on a theological foundation in a sermon delivered in honor of a deceased New York soldier, which reminded the assembled congregation that no such thing as sudden death exists in God's eyes, that the length of a human life is always exactly what God intends it to be. "God's time in taking every Christian home, is the full harvest time in that soul's earthly course." Such words were in part designed as consolation but also as instruction, as exhortation: if God is ready, we had better be too. As an 1863 obituary discourse for a Michigan officer admonished: "Sinner! Procrastinate not. Let his sudden death be to thee a warning." 27

Such understandings of fate no doubt encouraged one means that soldiers frequently used to defend themselves-spiritually, emotionally, ideologically-against sudden death. Many letters announcing the deaths of comrades commented on the deceased's premonitions that a particular encounter would indeed prove fatal. Even if these men were denied the few poignant and life-defining minutes or hours of knowing that their wound or illness would be their last, they had nevertheless seized their destiny through the mechanism of foresight. They had provided themselves with time for the all-important spiritual preparation one could use effectively only when face to face with unavoidable death. Sure knowledge - even of death-seemed preferable to persisting uncertainty, for it restored both a sense of control and the feeling of readiness so important to the Good Death. Willie Bacon, for example, had told his comrades of his conviction that he would die the night before he entered his last battle in Virginia in 1862. "Strange and mysterious," remarked the preacher who delivered his funeral sermon, "is the fact that God so often permits the shadow of death to be thrown upon us, that we may prepare ourselves for his coming." Early in the war, W. D. Rutherford of South Carolina remarked to his fiancée upon "[h]ow we find ourselves involuntarily longing for the worst," so as

\footnotetext{
${ }^{27}$ Letter to Mrs. Mason, October 3, 1864, Capt. Orren W. Barrow File, Twenty-Fourth Regiment, Virginia Infantry, CSA Collection, Brockenbrough Library; A[lexander]. S. Twombly, The Completed Christian Life: A Sermon Commemorative of Adjt. Richard M. Strong . . . (Albany, N.Y., 1863), 10; David Mack Cooper, Obituary Discourse on Occasion of the Death of Noah Henry Ferry, Major of the Fifth Michigan Cavalry . . . (New York, 1863), 30.
} 
simply not to be caught unaware. Rutherford would confront three more years of such uncertainty and "longing" before his death in Virginia in October $1864 .^{28}$

Wounded or sick soldiers who knew they had not long to live made their sense of preparedness explicit by indicating their acceptance of their fate, and letters offered such remarks as important vehicles of condolence to bereaved family members. J. C. Curtwright wrote with sadness to inform Mr. and Mrs. L. B. Lovelace of Georgia that their son had died in April 1862 in Tennessee. But, he reassured them, "[h]e was conscious all the time and expressed a willingness to die." $\mathrm{T}$. Fitzhugh wrote Mrs. Diggs to report the death of her beloved husband in June 1863. He lived "but a short while" after being shot by the Yankees, but "he was in his right mind at the time of his death" and "was perfectly resigned." A nurse in a Virginia military hospital informed the mother of a deceased patient that he had been "conscious of his death and . . not afraid but willing to die," which she reassuringly interpreted as "reason to believe that he is better off" now than in this world of woe. ${ }^{29}$

Witnesses eagerly reported soldiers' own professions of faith and Christian conviction, for these were perhaps the most reassuring evidences that could be provided of future salvation. As T. J. Hodnett exclaimed to his family at home after his brother John's 1863 death from smallpox, "Oh how coud I of Stud it if it had not of bin for the bright evidence that he left that he was going to a better world." Hodnett was deeply grateful that John's "Sole seme to be ... happy" as he passed his last moments singing of a heaven with "no more triels and trubble nor pane nor death." Captain A. K. Simonton of North Carolina and Isaac Tucker of New Jersey fought on different sides of

\footnotetext{
${ }^{28}$ Bacon, Memorial of William Kirkland Bacon, 57; W. D. Rutherford to Sallie Fair, July 26, 1861, Rutherford Papers. On premonitions of death see also Corby, Memoirs, 238-39; Alonzo Abernethy, "Incidents of an Iowa Soldier's Life, or Four Years in Dixie," Annals of Iowa, 3d ser., XII (October 1920), 408-9. For a Jewish example see the report on the death of Gustave Poznanski in "The Fight at Secessionville," Charleston Daily Courier, June 18, 1862, p. 1; Young, Where They Lie, 39-40. On presentiment and on soldiers' deaths more generally, see James M. McPherson, For Cause and Comrades: Why Men Fought in the Civil War (New York and Oxford, 1997), 63-71. See also E. S. Nash to Hattie Jones, August 19, 1861, Herbert S. Hadley Papers, Missouri Historical Society, St. Louis; and Wells, Facing the "King of Terrors," 162-63.

${ }^{29}$ J. C. Curtwright to Mr. and Mrs. L. B. Lovelace, April 24, 1862, in Lane, ed., Dear Mother, 116; T. Fitzhugh to Mrs. Diggs, June 23, 1863, File D-291A; and Sallie Winfree to Mrs. Bobo, October 9, 1862, Henry Bobo Papers, both in the Brockenbrough Library.
} 
the conflict, but both died with the words "My God! My God!" on their lips. Tucker was not a "professed and decided follower of Jesus," but his regular attendance at church, his calm in the face of death, and his invocation of the Divinity at the end suggested grounds for fervent hope about his eternal future. Simonton's presentiment of his end, his attention in the weeks before his death to "arranging his business for both worlds," indicated that he too was ready to greet his Maker, as he did explicitly with his last words. ${ }^{30}$

When soldiers expired unwitnessed and unattended, those reporting on their deaths often tried to read their bodies for signs that would reveal the nature of their last moments-to make their silence somehow speak. Their physical appearance would communicate what they had not had the opportunity to put into words. Many observers believed, as one war correspondent put it, that the "last life-expression of the countenance" was somehow "stereotyped by the death blow," preserved for later scrutiny and analysis. As a witness to the death of Maxcy Gregg wrote the general's sisters, "the calm repose of his countenance indicated the departure of one, at peace with God." In words meant to offer similar reassurance to grieving relatives, a Confederate soldier reporting the death of a cousin in 1863 described the body as he had found it: "His brow was perfectly calm. No scowl disfigured his happy face, which signifies he died an easy death, no sins of this world to harrow his soul as it gently passed away to distant and far happier realms." Clearly such a peaceful countenance could not be on its way to hell. A Michigan soldier, however, discovered just such evidence in the appearance of some "rebells" already many hours dead. "Even in death," he wrote, "their traits show how desperate they are and in what situation their conscience was. Our dead look much more peaceful." Letter writers eagerly reported any evidence of painless death, not just to relieve the minds of loved ones about the suffering a soldier might have had to endure, but, more importantly, because an easy death suggested the calmness, resignation, and quick passage to heaven the bereaved so eagerly hoped for as they contemplated the fate of their lost kin. ${ }^{31}$

${ }^{30}$ T. J. Hodnett, quoted in Davidson, ed., War Was the Place, 80, 77; Elijah Richardson Craven, In Memoriam, Sermon and Oration... on the Occasion of the Death of Col. I. M. Tucker ... (Newark, N.J., 1862), 5-6; Walter W. Pharr, Funeral Sermon on the Death of Capt. A. K. Simonton of Statesville, N.C. (Salisbury, N.C., 1862), 11.

${ }^{31}$ J[ames]. B. Rogers, War Pictures: Experiences and Observations of a Chaplain in the U.S. Army, in the War of the Southern Rebellion (Chicago, 1863), 182; J. Monroe Anderson to the 
Peaceful acceptance of God's will, even when it brought death, was an important sign of one's spiritual condition. But if resignation was necessary for salvation, it could not be sufficient. Condolence letters detailed evidences of sanctified practice that absent relatives had not been able to witness. When Henry Bobo, a Mississippi private, died of wounds received near Richmond in the summer of 1862, his cousin wrote from the field to assure Henry's parents that their son had a better chance of getting to heaven than they might think. There had been, he reported, a "great change" in Henry's "way of living" in the months just before his death. Although he had never actually become a professed Christian, Henry had quit swearing and had begun to lead a Christian life. I. B. Cadenhead's sergeant sought to offer similar reassurance to the soldier's widow after her husband's death outside Atlanta in the summer of 1864. "I have had several conversations with him upon the subject of death he sayed to me their was one thing that he was sorry for $\&$ and that he had not united himself with the church before he left home." When Asahel Nash was killed in the fall of 1862 , his parents wrote their nephews, who had served in the First Ohio with their son, to secure information about his life as well as his death. "[W]e want you to write all you can about Asahel ... . How were his morals?" The army, they feared, was "a poor place to improve good habits." 32

Perhaps Walter Perry had succumbed to the temptations of camp life, for his brother Frank reported that the soldier expressed great anxiety about his past behavior as he lay dying after Antietam. Frank wrote his family in Georgia that Walter at first "said that he hoped he was prepared to meet his God in a better world than this," but he knew

Sisters of Gen. Gregg, January 9, 1863, Maxcy Gregg Papers, South Caroliniana Library; Guy R. Everson and Edward W. Simpson, Jr., eds., "Far, Far From Home": The Wartime Letters of Dick and Talley Simpson, Third South Carolina Volunteers (New York and Oxford, 1994), 287; John Weissart to Dearest Wife and Children, October 17, 1862, Bentley Historical Library, University of Michigan, Ann Arbor. My thanks to Elana Harris for this citation. For a Catholic example of reading the body for signs of the state of the soul, see Sister Catherine to Father Patrick Reilly, December 5, 1862, Patrick Reilly Papers, Archives of the Archdiocese of Philadelphia, which described the death of Sister Bonaventure "with sweet peace and joy" and reported that "the peace and calm of her soul was evident on her countenance."

${ }^{32}$ L. S. Bobo to Dear Uncle, July 7, 1862, August 14, 1862, Bobo Papers; James T. Moore to [Leusa F.] Cadenhead, July 23, 1864, in "Some Confederate Letters of I. B. Cadenhead," 568; E. and E. Nash to Respected Nephews in Camp, November 11, 1862, Alpheus S. Bloomfield Papers, Library of Congress. 
"he had been a bad, bad, very bad boy." Frank had hastened to assure the dying man that Christ had come to save such sinners. And when Walter failed to mention any of the family by name, Frank emphasized that he had nonetheless addressed them implicitly by repeating "Good by, Good by to you all." Striving to fit his brother's life and words into the model of the Good Death, Frank Perry consoled his family with a report of Walter's expressed hope to "meet us all in Heaven." But hope in this case seemed considerably less than certainty. ${ }^{33}$

In a letter to his wife informing her of her brother George's death in 1864, Frank Batchelor made a similar effort to transform the deceased into a plausible candidate for salvation. Batchelor admitted that George "did not belong to the visible body of Christ's Church" but cited his "charity" and "his strong belief in the Bible" as well as his rejection of the sins of " "envy hatred and malice" to offer his wife hope for her brother's fate. Batchelor confirmed himself "satisfied" that George was "a man of prayer" and no doubt at last "found the Savior precious to his soul" before he died. "This being so," Batchelor happily concluded, "how sweet the consolation which comes to us through the promises of our Redeemer." His wife could comfort herself with the knowledge she would meet her brother again " "in the green fields of Eden." Frank Batchelor worked hard to construct a convincing letter of consolation, one that could provide his wife with real grounds for optimism about the fate of her brother's soul. ${ }^{34}$

Just as the bereaved looked for persuasive evidence of salvation, so too were they eager for last messages from dying kin. Reports of parting communications to loved ones appeared in almost every condolence letter. Sanford Branch wrote his mother in Georgia after First Manassas to say his brother John's last words were "about you ...." After Private Alfred G. Gardner of Rhode Island was shot at Gettysburg, the last thing he said was for his sergeant to tell his wife he died happy. T. J. Spurr of Massachusetts expired uttering the word "Mother"; Wiley Dorman "asked for his Mother the last word he spoke." Fathers often exhorted children to complete their education, help their mothers, and say their prayers. With these words, dying

\footnotetext{
${ }^{33}$ Frank Perry to J. Buchannon, September 21, 1862, in Lane, ed., Dear Mother, 189.

${ }^{34}$ Frank Batchelor to Dear Wife [Julia Batchelor], in H. J. H. Rugeley, ed., Batchelor-Turner Letters: 1861-1864: Written by Two of Terry's Texas Rangers (Austin, Tex., 1961), 80.
} 
soldiers brought at least the names and spirit of absent loved ones to their deathbeds and left their survivors with wishes and instructions that outlived their source. For those at home, news of these final messages reinforced the sense of connectedness to lost kin. Neither family nor soldier was left entirely alone, for these deathbed invocations of absent loved ones worked in some measure to overcome separations. ${ }^{35}$

Soldiers seemed often to invoke names of kin in messages of reassurance-about their certainty of salvation and of meeting them once again in "a better world than this." "Write to mother," implored a dying soldier, "and tell her she must meet me in heaven. I know I am going there." But this soldier, like many others, went beyond the traditional elements of the Ars Moriendi in his efforts to provide his mother with consolation. "Tell my mother," he was reported to have said, "I have stood before the enemy fighting in a great and glorious cause . . .." When Civil War condolence letters enumerated evidence of the deceased's Christian achievements, designed to show his eligibility for salvation, the writer often included details of the soldier's military performance, his patriotism, and his manliness. In a letter to the widow of a comrade who had died the preceding day, T. Fitzhugh reported all the customary information: her husband had been resigned to death, was conscious of his fate, and sent his love to wife and children. But he also added that the soldier had "died a glorious death in defence of his Country." 36

The image of the Christian soldier encompassed patriotic duty within the realm of religious obligation. But in some instances, patri-

\footnotetext{
${ }^{35}$ Sanford Branch to his mother, July 26, 1861, in Lane, ed., Dear Mother, 36 (first quotation); Coco, Killed in Action, 91; Alonzo Hill, In Memoriam. A Discourse . . on Lieut. Thomas Jefferson Spurr (Boston, 1862) (second quotation); Davidson, ed., War Was the Place, 119 (third quotation). Chaplain Corby observed that nearly all men called to their mothers as they lay dying (Corby, Memoirs, 95), and this was enshrined in Civil War popular songs; see, for example, Thomas MacKellar, The Dying Soldier to His Mother, broadside (New York, n.d. [1860s]), and C. A. Vosburgh, Tell Mother, I Die Happy, broadside, (New York, 1863). For an example of a song popular in the South see Charles Carroll Sawyer, Mother Would Comfort Me!, broadside (Augusta, Ga., n.d. [1860s]). There were so many songs written as messages to mother from the battlefield that they began to generate parodies and satirical responses. See John C. Cross, Mother on the Brain, broadside (New York, n.d. [1860s]); and Cross, Mother Would Wallop Me, broadside (New York, n.d. [1860s]).

${ }^{36}$ William W. Bennett, A Narrative of the Great Revival Which Prevailed in the Southern Armies During the Late Civil War Between the States of the Federal Union (Philadelphia, 1877), 243-44; T. Fitzhugh to Mrs. Diggs, June 23, 1863. For a letter in almost identical language see E. W. Rowe to J. W. Goss, December 16, 1863, Capt. William W. Goss File, Nineteenth Virginia Infantry, CSA Collection, Brockenbrough Library.
} 
otism and courage seemed to serve as a replacement for evidence of deep religious faith. Oliver Wendell Holmes lay severely wounded after Ball's Bluff, wondering if his religious scepticism was going to put him "en route for Hell." But he urged his physician to write home in case of his death to say he had done his duty. "I was very anxious they should know that." Some nonbelievers hoped that patriotism would substitute for religious conviction in ensuring eternal life. A dying Confederate asked his friend, "Johnnie if a boy dies for his country the glory is his forever isn't it?" He would have found the views of David Cornwell of the Eighth Illinois reassuring. "I couldn't imagine," he mused, "the soul of a soldier who had died in the defense of his country being consigned to an orthodox hell, whatever his opinion might be of the plan of salvation." ${ }^{37}$

But Cornwell's views, widely held in both armies, seemed to many Protestant clergy an unwarranted theological innovation, generated by earthly necessities rather than transcendent truths. As the Army and Navy Messenger, published in Virginia by the interdenominational Evangelical Tract Society, warned in 1864, patriotism was not piety. "It is not the blood of man but 'the blood of Jesus Christ that cleanseth from all sin." 38

Yet despite clerical efforts, the boundary between duty to God and duty to country grew increasingly blurred, and dying bravely and manfully came to comprise a significant part of dying well. For some soldiers it almost served to take the place of the more sacred obligations of holy living that had traditionally prepared the way for the Good Death. Letters comforting Wade Hampton after his son Preston was killed in the fall of 1864 emphasized this juxtaposition of military and Christian duty and sacrifice. William Preston Johnston urged Hampton to remember that his son's "heroism has culminated in martyrdom,"

\footnotetext{
${ }^{37}$ Mark DeWolfe Howe, ed., Touched With Fire: Civil War Letters and Diary of Oliver Wendell Holmes, Jr., 1861-1864 (1947; repr., New York, 1969), 27; A. D. Kirwan, ed., Johnny Green of the Orphan Brigade: The Journal of a Confederate Soldier (Lexington, Ky., 1956), 37; David Cornwell, quoted in Hess, The Union Soldier in Battle, 143.

${ }^{38}$ Army and Navy Messenger, April 1, 1864, quoted in Berends, "Wholesome Reading,", 132-33, 154 (quotation on p. 154). See also Fales Henry Newhall, National Exaltation: The Duties of Christian Patriotism . . . (Boston, 1861); William Adams, Christian Patriotism (New York, 1863); Joseph Fransioli, Patriotism: A Christian Virtue. A Sermon Preached... at St. Peter's Church, Brooklyn, July 26th, 1863 (New York, 1863). Also note Sister Matilda Coskey's disapproval of a father who refuses to permit his wounded son to be baptized, arguing "he has served his country, fought her battles \& that is enough-he has nothing to fear for his soul." Sister Matilda Coskey to Father Patrick Reilly, October 18, 1864, Reilly Papers.
} 
which should serve as a "consolation for the years he might have lived." James Connor's letter to Hampton merged the imperatives of Christianity, military courage, and masculinity into a hierarchy of condolence. "Your best consolation will I know my dear Genl," he wrote, "be drawn from higher than earthly sources[;] still some alleviation of the sorrow is to be drawn from the reflection that Preston died as he had lived, in the path of duty and honor. Young as he was he had played a man's part in the war." Although Christian principles remained paramount, considerations of courage and honor could also offer "some alleviation of the sorrow" and thus played a significant role in the Civil War condolence letter as well as in more general conceptions of holy living and holy dying. A letter written from North Carolina in 1863 to inform William K. Rash that "your son R. A. Rash is no more" is striking in its deviation from the conventional model. It includes no mention of God or religion, simply reporting the ravages of "the Grim monster Death." All the more significant, then, is its invocation of the only solace available in the absence of appeal to the sacred: "But one consolation he died in the full discharge of his duty in the defence of his home \& Country." 39

For some, even the comfort of manly duty bravely accomplished proved unavailable. Commanding officers, chaplains, nurses, and friends did all within their power to cast each death as good, to offer grounds for hope to the bereaved, for they self-consciously sought to provide both information and condolence in their communications from battle to homefront. As one postwar chronicler explained, the Catholic Sisters of Mercy who nursed eighteen-year-old David Brant "wrote to his father the least painful account possible of the poor son's death." Indeed, attendants of the dying may not have simply waited to report a good death but worked instead to compel it by demanding courage and calmness from the moribund or, as Catholic nurses and chaplains frequently reported, by winning consent for last minute baptisms. Undoubtedly, these observers were struggling to manage and mitigate some of the horror of the slaughter they encountered daily. ${ }^{40}$

\footnotetext{
${ }^{39}$ William Preston Johnston to Wade Hampton, November 3, 1864; James Connor to Wade Hampton, November 6, 1864, Wade Hampton Papers; and N. A. Foster to William K. Rash, Fifty-second North Carolina Papers, both in the Brockenbrough Library. For another discussion of gallantry see Eleanor Damon Pace, ed., "The Diary and Letters of William P. Rogers, 18461862," Southwestern Historical Quarterly, XXXII (April 1929), 298-99.

${ }^{40}$ George Barton, Angels of the Battlefield: A History of the Labors of the Catholic Sisterhoods in the Late Civil War (Philadelphia, 1897), 181; Linderman makes a similar point about such compulsion in Embattled Courage, 30; Smith, ed., "Notes on Satterlee," 433-34; Berends, “"Wholesome Reading'," 137.
} 
The genre of the condolence letter, the main vehicle for recording and transmitting information about soldiers' last moments, provided no place for "Bad Deaths," for there was no motivation to communicate such information to survivors. But sometimes what one Confederate chaplain called "fond and comforting hope" was all but impossible. Hugh McLees, a missionary to South Carolina regiments, noted that " $[\mathrm{t}]$ he deathbed of an impenitent and unpardoned sinner is a very awful place yet it is one where I have been often called to stand." To standbut not to describe. Yet some depictions of Bad Deaths survive because such climaxes could be as "edifying" as ideal or "triumphant" ones. Reports of painful, terrifying deaths served as powerful warnings when they were included in religious tracts, newspapers, and chaplains' memoirs. Father Louis-Hippolyte Gache, a Confederate chaplain, found Freemasons especially likely to die badly, obstinate in rejecting faith to the end. Gache described a man who cursed both him and the church in his "last agony" and thus left his family with a "twofold bereavement: they mourned his physical, and with much more grief, his spiritual death."41

Perhaps the most widespread version of the Bad Death appeared in the narratives of soldiers' executions that can be found not only in religious publications and writings but in almost every surviving soldier's diary and every substantial collection of soldiers' letters. Executions, more frequent in the Civil War than in any other American conflict before or since, had a disciplinary purpose: they were staged before assemblies of troops and designed to make a powerful impression. The Charleston Mercury described soldiers seized by "uncontrollable emotion" as their division formed a three-sided square to witness the execution of ten deserters. Soldiers who sat on their coffins as they awaited the firing squad or stumbled up the steps to the gallows represented a powerful warning to those who would die well, rather than in shame and ignominy. An execution compelled its witnesses literally to confront death and to consider the proper path towards life's final hour. In the case of execution of deserters, the ceremony offered a particularly pointed implied contrast between the Good Death in

\footnotetext{
${ }^{41}$ Hugh McLees to John [McLees], December 20, 1863, John McLees Papers, South Caroliniana Library; Berends, “'Wholesome Reading'," 139 n. 21; Buckley, trans., A Frenchman, A Chaplain, A Rebel, 164. On bad deaths see also Houlbrooke, Death, Religion, and the Family, 207.
} 
combat and the disgraceful end meted out to those seeking to escape battle's terrors. But executions provided more than just negative examples. The condemned served in many cases as exemplars of hope, for chaplains struggled to save these unfortunates from "the second death" and to use them to transmit a powerful educational message. Calm resignation, last-minute expressions of repentence, the enactment of elements of the Good Death even at the foot of the gallows, sometimes even an address from the prisoner urging his fellow soldiers to "beware of his untimely fate"-all provided indelible messages about both good living and good dying, ones that witnesses took very much to heart. These deaths, remarked Catholic chaplain William Corby, "were harder on the nervous system than the scenes witnessed in the midst of a battle, where there is rattle, dash, and excitement to nerve one up for the occasion." As a Confederate private remarked in a letter to his wife, seeing a man die in this way was "awful"-at once horrible and inspiring of awe. Almost any soldier could have written the words penned by one witness to an execution in 1863: "I don't think I shall ever forget the scene." 42

Military executions made a powerful statement about the need to be prepared to die. As the condemned prisoner scrambled to change his eternal fate with a last-minute conversion or repentence, he reinforced the centrality of readiness to the Good Death. Spiritual preparedness was of course the essence of the art of dying well, but preparation was often also manifested in more temporal ways. Many popular renditions of the Ars Moriendi emphasized the importance of settling one's worldly affairs, and these considerations found their way into soldiers' letters and soldiers' lives. A soldier who arranged for a burial plot on a furlough home was clearly contemplating his mortality in the manner necessary for dying well. But he was also disposing of earthly preoccupations so that his death might bring a satisfactory conclusion to

\footnotetext{
${ }^{42}$ Laderman, Sacred Remains, 99; Robert I. Alotta, Civil War Justice: Union Army Executions Under Lincoln (Shippensburg, Pa., 1989); Charleston Mercury, September 18, 1863 (first quotation); John Ripley Adams, Memorial and Letters of Rev. John R. Adams, D.D. . . (Cambridge, Mass., 1890), 123 (second quotation); letter from Guilburton, September 4, 1863 (third quotation); and Henry Robinson to his wife (fifth quotation), both in Lane, ed., Dear Mother, 263-64, 107; Corby, Memoirs, 248 (fourth quotation); Frances Milton Kennedy Diary, September 26, 1863, Southern Historical Collection (sixth quotation). For examples of descriptions of executions see McAvoy, ed., "War Letters of Father Peter Paul Cooney," 57. On the disgrace of dying badly see Mary Acton Hammond, ed., "'Dear Mollie': Letters of Captain Edward Acton to His Wife, 1862," Pennsylvania Magazine of History and Biography, LXXXIX (January 1965), 28.
} 
life's narrative. Condolence letters almost inevitably addressed these concerns, usually in their closing sentences or paragraphs. Correspondents often elevated an accounting of soldiers' property and back pay into more transcendent realms by including descriptions of relics or memento mori they were forwarding to bereaved kin. Burns Newman of the Seventh Wisconsin Volunteers undertook the "painful duty" of informing Michael Shortell's father of his son's death near Petersburg the preceding evening. "Enclosed," he continued, "send you some trinkets taken from his person by my hand. Think you will prize them as keepsakes." A Bible, a watch, a diary, a lock of hair, even the bullet with which a son or brother had been killed could serve to fill the void left by the loved one's departure, could help to make tangible a loss known only through the abstractions of language. Henry I. Bowditch of Massachusetts described an "amulet" he fashioned out of a ring given his dead son Nathaniel by his fiancée and a "cavalry button cut from his blood-stained vest." Bowditch attached them to his watch. "There I trust they will remain until I die." John S. Palmer of South Carolina carried the ball that had killed his son James with him until he died in 1881 , when he took it with him to his grave. ${ }^{43}$

Condolence letters often provided kin with an opportunity for the most important lingering connection with the dead: information about burial, news of a gravesite that could be visited, or the location of a body that might someday be retrieved. Letter writers did their best to provide the consolation of a "decent" burial-mentioning when they could that a coffin had been provided, that a grave had been marked to preserve the identity of the deceased from oblivion. When James Vance of the Thirty-sixth Wisconsin Volunteers wrote Mr. and Mrs. Patton of the death of their son Wesley in Virginia in June 1864, he reassured them that "we buried him decently placed a board with his name, day of death, age and regiment, to his grave that he may be found at any time should you care to move him. I tried all I could to send his body home and the Sargant tried but could not do it." A letter might include directions to a grave, sometimes with descriptions of

\footnotetext{
${ }^{43}$ Burns Newman to Mr. Shortell, May 24, 1864, Michael Shortell Letters, State Historical Society of Wisconsin, Madison; Henry I. Bowditch, Memorial Volume for Nathaniel Bowditch, 1036, Nathaniel Bowditch Memorial Collection, Massachusetts Historical Society; Louis P. Towles, ed., A World Turned Upside Down: The Palmers of South Santee, 1818-1881 (Columbia, S.C., 1996), 650, 761, 871. See also Disposition of Personal Effects of Dead Wisconsin Soldiers, 1863, Governor's Papers, State Historical Society of Wisconsin.
} 
landmarks—an oddly shaped rock, for example, or a particular species of trees. ${ }^{44}$

All too often, however, a body could not be located, much less returned. When W. N. Pendleton, an Episcopal minister as well as a Confederate general, wrote William Garnett of the death of his son General Richard B. Garnett in Pickett's Charge, he felt pained to report that "his body, in common with those of many officers there, was not recovered." This was rarely the case for a general, but it was all too common among the rank and file, for hundreds of thousands of men remained missing or unidentified at war's end. Knowing where a loved one had been "decently interred" was a precious consolation indeed. The effort to identify and rebury the Union and Confederate dead after Appomattox was in many senses a continuation of the imperatives of the Ars Moriendi into the postwar years. Long after the dying was over, Americans North and South sought to add epilogues to their wartime death narratives. ${ }^{45}$

Even before war's end, Americans had begun to revise and elaborate the accounts of death focused on the hors mori. The condolence letter came in many cases to represent a rough draft of a story of holy living and holy dying that was rewritten and perfected in a range of printed genres dedicated to constructing the Good Death amid the chaos of wartime destruction. Obituaries often replicated the structure and content of condolence letters, frequently even quoting them directly, describing last moments and last words and assessing the likelihood of a deceased soldier's salvation. William James Dixon of the Sixth Regiment of South Carolina Volunteers, his obituary reported, had not entered the army as a believer, though he had always "maintained a strictly moral character." Several battles, however, impressed him with "the mercy of God in his preservation," so that before his death at Chancellorsville he had "resolved to lead a new life." His loved ones could, the Daily South Carolinian assured them, safely "mourn not as those who have no hope" and could be certain "that their loss is his eternal gain." 46

\footnotetext{
${ }^{44}$ James Vance to Mr. and Mrs. Patton, June 6, 1864, Wesley W. Patton Papers, State Historical Society of Wisconsin. See the extraordinary description of the condition of the corpse in M. D. Locke's letter of August 14, 1861, informing Dr. James D. Rumph of the death of his son Langdon, in Henry Eugene Sterkx and Brooks Thompson, eds., "Letters of a Teenage Confederate," Florida Historical Quarterly, XXXVIII (April 1960), 344-45.

${ }^{45}$ W. N. Pendleton to William Garnett, July 9, 1863, File G-392, Brockenbrough Library.

${ }^{46}$ Daily South Carolinian, May 29, 1864. For other examples see the obituaries of William James Dixon, May 29, 1864; W. W. Watts, August 23, 1864; H. L. Garlington, August 13, 1864; Milton Cox, August 9, 1862; Joseph Friedenberg, September 15, 1862, all in the Daily South
} 
Funeral sermons and biographies of the deceased, ranging in size from a pamphlet of a few pages to full-sized octavoes, appeared in print both North and South, further elaborating the narratives of the Good Death. Usually financed by grieving kin, the writings were designed to serve as memorials to the dead and as exhortations to the living. Almost without exception, they drew explicitly on details within condolence letters to fashion a more formalized and self-conscious story of a life and its meaning. In his funeral sermon for John W. Griffin, a young Confederate chaplain who died in 1864, L. H. Blanton referred to descriptions of the deceased's last words and judged that Griffin's "dying testimony was all that Christian friends or the Church of God could desire." Printed sermons or memorials often included the full text of the battlefront letter within an appendix. But the particular circumstances of death served as the foundation for broader consideration of an entire life. Here the presentation of a life turned to the narrative of death as a kind of touchstone, a basis for assessing the meaning and value of the larger whole. More polished than condolence letters written from the front, these published genres were intended for distribution to a wider audience than simply next of kin. But they nevertheless reveal a persisting concern with the Good Death, with the transcendent symbolic and substantive importance of life's last moments. Designed more to extol than to console, these writings endeavored to capture the essence of a life in a form that would ensure it would be remembered, to place the life within a cultural narrative of holy living and holy dying that would make it intelligible and thus both meaningful and memorable. The funeral sermon and the published biography were memorials, not in granite, but in words, memorials that sought, like the Good Death itself, to ensure that dying was not an end but a foundation for immortality — of eternal life, of lasting memory. ${ }^{47}$

Dabney Carr Harrison's death and its translation into printed form exemplified this effort. When he was shot through the lungs at Fort

Carolinian; George Nichols in the Richmond Daily Whig, December 24, 1862; Walter Matthews in the Richmond Daily Dispatch, December 25, 1862; the account of Isaac Valentine's death in "The Fight at Secessionville," Charleston Daily Courier, June 18, 1862; and the obituary for Thomas B. Hampton, unidentified newspaper clipping, n.d. [March 1865], in the Hampton Papers, Center for American History.

${ }^{47}$ L. H. Blanton, "Well Done thou good and faithful servant," Funeral Sermon on the death of Rev. John W. Griffin, chaplain of the 19th Va. Regt. (Lynchburg, Va., 1865), 8. On funeral sermons see Larissa Juliet Taylor, "Funeral Sermons and Orations as Religious Propaganda in Sixteenth-Century France," in Bruce Gordon and Peter Marshall, eds., The Place of the Dead: Death and Remembrance in Late Medieval and Early Modern Europe (Cambridge, Eng., and New York, 2000), 224-39; and Houlbrooke, Death, Religion, and the Family, Chap. 10. 
Donelson, he murmured, "It is all right! I am perfectly willing to die." For Reverend William James Hoge, composing a sketch of Harrison's life, this phrase became the all-important message of Christian sacrifice, an emulation of the Savior himself: " $[\mathrm{H}]$ owever bitter the cup of pain and grief put into his hands by his heavenly Father, he would still say as he drank, 'It is all right." The entire life Hoge recounted became a prelude to this final, defining moment. Born on the Sabbath, Harrison died on the Sabbath, "his life bounded on either hand by the Day of God." 48

Just as the purpose of the condolence letter was, when possible, to comfort the bereaved with evidence that the deceased had demonstrated his claim on eternal life, so too the obituary, the funeral sermon, and the death biography marshalled evidence of holiness, usually from the assessment of an entire life for which the Good Death served only as climax. In his Sketch of the Life of Randolph Fairfax, Reverend Philip Slaughter noted that the dead Confederate always played fairly as a boy and obeyed his mother, had requested a Bible for his fourteenth birthday, and carried a New Testament in battle. When he was killed instantly by a shell at Fredericksburg, the testimony of his life served, in Slaughter's view, to provide the certainty of salvation that Fairfax had himself been unable to articulate. As Reverend Robert L. Dabney explained in his memorial to Lieutenant Colonel John T. Thornton, "he being dead, yet speaketh" through the "narrative of ... [his] religious life," a life that Dabney then proceeded to relate. ${ }^{49}$

Soldiers remembered in funeral orations and printed biographies were obviously individuals of considerable importance, with families of sufficient means to sponsor these memorials. Almost always they were officers. These soldiers are markedly less representative of the masses of Civil War armies than are the men whose deaths were reported in the stream of private condolence letters written by comrades to send news of particular deaths to loved ones at home. Yet the existence of these more elaborated printed efforts to grapple with death

\footnotetext{
${ }^{48}$ William J[ames]. Hoge, Sketch of Dabney Carr Harrison, Minister of the Gospel and Captain in the Army of the Confederate States of America (Richmond, 1862), 50 (first quotation), 51-52 (second quotation), 53 (third quotation).

${ }^{49}$ Philip Slaughter, A Sketch of the Life of Randolph Fairfax: A Private in the Ranks of the Rockbridge Artillery... (Richmond, Va., 1864; microfilm, Confederate Imprints, reel 84), 6, 8, 35, 39; R[obert]. L[ewis]. Dabney, A Memorial of Lieut. Colonel John T. Thornton of the Third Virginia Cavalry, C.S.A. (Richmond, 1864), 6, 8.
} 
and its meaning suggest the ways in which the condolence letter served only as a beginning for the bereaved of all classes and stations. The cultural, emotional, spiritual, and ideological work that the privileged sought to accomplish by means of printed funeral sermons and death biographies was work that mourners from ordinary families would have needed to undertake as well-even if they lacked the resources to publish books and pamphlets that would be available to researchers more than a century later. It seems safe to assume that beneath these countless historical silences, ordinary Americans were also struggling to come to terms with their losses, carrying the concerns addressed in the condolence letter into their postwar lives.

The construction of the Good Death became a persisting imperative in the aftermath of Civil War slaughter, for it had not been fully accomplished even at war's end. It seems useful to suggest that we attend to the way the Ars Moriendi continued to exert power after the war-and served as a determining force in efforts to identify and rebury missing soldiers, to memorialize Union and Confederate dead. For example, when William Cox delivered an address on the "Life and Character" of Stephen Ramseur to the Ladies Memorial Association of Raleigh, North Carolina, in May 1891, nearly thirty years after the Confederate general's death at Cedar Creek, the orator included with "no apology" the text of the 1864 condolence letter sent by Major R. R. Hutchinson to announce the Confederate officer's death to his wife. The assumptions of the Ars Moriendi would retain their hold and ultimately contribute to a sectional reconciliation grounded not so much in the genuine resolution of political differences as in national acknowledgment of the shared experience of death and loss. ${ }^{50}$

The political meanings of the Civil War remained bitterly contested well into the twentieth century, as Reconstruction proved, in Eric Foner's words, an "unfinished revolution," and as definitions of freedom and citizenship continued to divide Americans. ${ }^{51}$ Even as a new century begins, we find ourselves still embroiled in struggles about the Civil War's legacy, forcefully represented in the year 2000 in controversies over the flying of the Confederate flag. Yet in the generations

\footnotetext{
${ }^{50}$ William R. Cox, Address on the Life and Character of Maj. Gen. Stephen D. Ramseur Before the Ladies' Memorial Association of Raleigh, N.C., May 10th, 1891 (Raleigh, 1891), 45-47, 50-51 (quotation on p. 50). Thanks to Gary Gallagher for bringing this to my attention.

${ }^{51}$ Eric Foner, Reconstruction: America's Unfinished Revolution, 1863-1877 (New York and other cities, 1988).
} 
that followed the Civil War and Reconstruction, many of these political differences became gradually muted as much of the nation redirected its interest in the war to the work of memorialization, into a focus on the heritage of loss and mourning common to both sections. The assumptions of the Ars Moriendi had been widely shared during the war. In the establishment of seventy-three national cemeteries, in the evolution of Memorial Days North and South, in the erection of monuments to the slain in courthouse squares from New England to Texas, the Good Death became an ongoing national preoccupation. More often expressed as the notion of common "sacrifice," the centrality of death-endured North and South-has become critical to our shared national narrative of the war's ultimate meaning.

A historian in the twenty-first century cannot but be struck by how hard Civil War Americans struggled to construct Good Deaths for themselves and their comrades amid conditions that made death-and life-so terrible. As war continued inexorably onward and as death tolls mounted ever higher, soldiers on both sides reported how difficult it became to believe that the slaughter was purposeful and that their sacrifices had meaning. Officers, doctors, privates, and nurses all reported processes of gradual numbing in the face of battle's horrors, the adoption of attitudes of "stoical indifference" to the bodies littering the battlefields of 1864's especially bloody campaigns. Yet the narratives of the Ars Moriendi continued to exert their power, as soldiers wrote letters home about comrades' deaths that resisted and reframed war's carnage. Men did not do this simply to mislead the bereaved with the purpose of easing their pain-a ruse Jay Winter attributes to the selfconsciously deceptive letters from the Western Front in World War I- - even though the authors of Civil War condolence letters did try their utmost to cast the deaths they described in the best possible light. But these letters are striking in their apparent commitment to honesty, their efforts at scrupulousness in reporting when a deceased soldier's faith had been suffused with doubt, when his behavior had been less than saintly. Civil War soldiers seem themselves desperately to have wanted to believe in the narratives they told and in the religious assumptions that lay behind them. The letters may have served in part as a way of reaching across the chasm of experience and horror that separated battle and homefront, as an almost ritualized affirmation of those very domestic understandings of death that had been so profoundly challenged by circumstances of war, as a way of moving symbolically out of the meaningless slaughter back into the reassuring mid-nineteenthcentury assumptions about life's meaning and purpose. Narratives of 
dying well may have served as a kind of lifeline between the new world of battle and the old world at home. ${ }^{52}$

In the eyes of a modern reader, men often seem to have been grasping at straws as they sought to present evidence of a dead comrade's ease at dying or readiness for salvation. But their evident effort provides perhaps the most eloquent testimony of how important it was to them to try to maintain the comforting assumptions about death and its meaning with which they had begun the war. In the face of the profound upheaval and chaos that the Civil War brought to their society and to their own individual lives, Americans North and South held tenaciously to deeply rooted beliefs that would enable them to make sense out of a slaughter that was almost unbearable. Their Victorian and Christian culture offered them the resources with which to salve these deep spiritual wounds. Ideas and beliefs worked-in good measure successfully - to mitigate, even to overcome the physical devastation of battle.

Yet such an analysis-one that sees the Good Death as a triumph of mind over matter, of belief over terrible reality-comes dangerously close to making implicit judgments about these past actors, to suggesting that they were on some profound level just deluding themselves in ways that we today are too sophisticated to indulge. I have described Civil War soldiers and civilians struggling to fit their experience into the narrative of the Good Death; I have portrayed them in the very telling of their lives endeavoring to gain control over their experience by imposing a consoling sense of meaning upon it. But they would not have seen themselves in this way. Their faith assured them that the meaning was there to be discovered, not introduced or invented by human minds. God, not they, was in their view the Great Narrator; humans had only to uncover his stories and to place them in the context of the broader tale of Christian sacrifice and salvation. Their religious faith made their culture very different from our more secular age. Although we may, as Stephen Elliott suggested, face "like miseries," we cannot look to "like consolations."

If we simply translate their experience into our own secular language of historical explanation, we inevitably lose much of the essence of their world. In spite of the supposed wisdom the historian expects to derive from hindsight, I have been humbled by an awareness of the power of these soldiers' rendering of their experience and by the

\footnotetext{
${ }^{52}$ Winter, Sites of Memory, 35; Washington Davis (1888), quoted in Linderman, Embattled Courage, 241. On numbness see Faust, "Riddle of Death," 21.
} 
recognition of how it enabled 620,000 Americans to die in a conflict that transformed the nation. For all my presumptions to historical insight, I cannot deny the knowledge and understanding that these men possessed and that I lack. As Herman Melville so eloquently observed in an 1866 poem entitled "The Armies of the Wilderness":

None can narrate that strife in the pines,

A seal is on it-Sabaean lore!

Obscure as the wood, the entangled rhyme

But hints at the maze of war-

Vivid glimpses or livid through peopled gloom,

And fires which creep and char-

A riddle of death, of which the slain

Sole solvers are. ${ }^{53}$

${ }^{53}$ Herman Melville, Battle-Pieces and Aspects of the War: Civil War Poems (1866; repr., New York, 1995), 103. What I am arguing here seems to me consistent with points Caroline Bynum made in her American Historical Association presidential address in which she urged that we not flatten the past with our presentism, that we resist appropriating it for our own purposes, and that we retain the capacity for wonder that enables us to understand our difference from those who have come before. "Every view of things that is not wonderful is false." Caroline Walker Bynum, "Wonder," American Historical Review, CII (February 1997), 26. 